\title{
ONE BELT, ONE ROAD INITIATIVE AND ITS GEOSTRATEGIC SIGNIFICANCE FOR EASTERN EUROPE
}

\author{
Ana PANTEA \\ "Babeș-Bolyai” University, Cluj-Napoca, Romania \\ anapantea@yahoo.com
}

\begin{abstract}
China's Belt and Road Initiative (BRI), as it was formally announced by President Xi Jinping in 2013, it is an engine for foreign policy, but it represents as well the driver force of China's economic growth - and as such, it plays an important role in the domestic policy. China's foreign policy aims to support domestic growth and employment, must be aligned with the narratives of 'rejuvenation' and the 'China Dream'. As such, the present paper discusses the origins and development of BRI; it analyses the mechanism in which BRI promotes China's domestic agenda; as well as it regards at the geostrategic aims and difficulties of such an ambitions global project.
\end{abstract}

\section{Keywords: China, Belt, Road Initiative (BRI), Eastern Europe, Romania}

\section{INTRODUCTION}

China's Belt and Road Initiative (BRI) [1], articulated by President Xi Jinping, was commenced in 2013 under the name One Belt One Road [2]. This development strategy represents much more than "physical connections" [3], as it aims an extensive cooperation in terms of economic development, trade, financing collaboration, social and cultural undertakings, as well as allotments [4]. It is essential to take note of the strategic geopolitical importance, since the BRI not only impacts China, but also the rest of the world. Many academics agree that the BRI represents a leadership attitude and a sophisticated sense of dynamism, maintaining the status qua.

In 2015, three major institutions (i.e. the National Development and Reform Commission, the Ministry of Foreign Affairs and the Ministry of Commerce of the People's Republic of China) delivered "an official document that described the measures and objectives of the Belt and Road Initiative for the first time in detail"[5]. BRI has five different components: three addressing economic items and the other two referring to strategic segments [6]. Hence, it is indicative to express that this "grandiose project" [7] is fundamentally a revival of various commercial practices which go hand in hand with China's desire "to remaking the whole world-via the Belt and Road Initiative and a new type of international relations, in particular - into a global community of common destiny" [8]. The primary imperative of "the most ambitious foreign policy approach adopted by China thus far [...] is to integrate all countries on the Eurasian landmass" [9].

Inspired by the ancient Silk Road, contemporary BRI is based on factual obeservation as it "follows the same principles... and thus keeps the heritage in a new way" [10]. The same document delivered by the Chinese government stipulates: "For thousands of years, the Silk Road Spirit - "peace and cooperation, openness and inclusiveness, mutual 
learning and mutual benefit" - has been passed from generation to generation, promoted the progress of human civilization, and contributed greatly to the prosperity and development of the countries along the Silk Road. Symbolizing communication and cooperation between the East and the West, the Silk Road Spirit is a historic and cultural heritage shared by all countries around the world"[11].

Additionally, it is far-reaching to remark that the BRI became "formulated under the principles of joint discussion, coconstruction and co-sharing"[12].

The complexity of BRI is due to the blend of domestic and international affairs. Firstly, in 2014, China's foreign minister himself, Wang $\mathrm{Yi}$, revealed that the BRI is the fresco of Xi's presidency [13]. The BRI may become the catalyst that has the power to bring "long-term improvement in China's relations with Europe" [14]. Secondly, analogies have already been drawn between BRI and the well-known (American) Marshall Plan [15], which supply pervasive incentives to the project itself, as well as some degree of pressure. Thirdly, there is still in place an undetermined official categorization of the project [16]. Fourthly, there is a generic shortage - or perhaps even lack - of knowledge regarding BRI [17]. Fifthly, the BRI incorporates "overlapping elements"[18] of infrastructure [19] which should indicate "upgraded and developed transcontinental railway routes, highways, port facilities and energy pipelines"[20]. And lastly, the fact that some 60 countries [21] are meant to take part in this project, in times of unprecedented multi-polarity.

This last (sixth) point just mentioned above shall be regarded as fundamentally important. From a broader perspective, when discussing both the BRI and the two elements entailed in the argument, it is important to raise two major questions: How will China manage to keep up the pace with the entanglement of other economic and political blocs? What is China's strategy in its endeavor to maximize the gains and benefits in its attempt to determine countries to take full commitment regarding the BRI? From one perspective, there is an existing cleavage within this context. Less fortunate countries, such as Pakistan, for example, had blindly expressed true devotement to the BRI. Inter alia, this is due to the historical baseline of bilateral relations, Pakistan's competition with other state actors in the region and the dispersed, perhaps even irregular aid coming from Western countries. The true tenure of the BRI, whatsoever, is not concerning China's Asian or African targets, partners, but those European actors, whose countries represent the final destination of the BRI.

Beyond any doubt, the BRI represents "a great opportunity" [22] for Europe, even thought since its launch, it has been perceived with reluctance, and reactions have been described as "lukewarm" [23]. It is questionable that the idea that the BRI has been rejected from the initial phase, but is it notably important to mention the fact that Europeans indeed have demonstrated mixed feelings toward the Initiative. One of the reasons can be is that Europe has been experiencing, for the past decade, economic, political and social challenges, if not difficulties, while the supranational and intergovernmental mechanisms in Brussels are burdened by bureaucracy. Also, "pressure from the United States... and concerns that the China-led bank [24] may not uphold high standards for good governance or environmental and social protections" [25] might represent subsequent reasons to argue reluctance. Nonetheless, China did not articulate clearly enough from the very beginning all the means and dimensions of BRI.

Despite the notions that exist regarding Europe's reaction to BRI, President $\mathrm{Xi}$, in 2014, pushed "bilateral relations between China and EU institutions" by means of proposing a partnership aimed at strengthening and advancing the cooperation "to a new level" [26]. After all, "China and the EU are not in competition they are in fact highly complementary" [27]. 
Once Beijing delivered the objectives two years ago, those economic items and strategic segments targeting the BRI, Europe's position started to change. Various European Union (EU) Member States joined the AIIB, cooperation under the $16+1$ framework increased, while other Chinese foreign policy strategies, such as Panda Diplomacy, completed the picture. It is of crucial importance, whatsoever, to keep in mind that European political mechanism and European socio-economic spectrum enhance a peculiar conglomerate. In Brussels, decision making and, ultimately, decision taking procedures are lengthier in terms of resources and time management. Indeed it is a challenge to converge 28 different interests into a single one, and deliver it unequivocally to the world. This requires patience, and since "China's foreign policy has moved from risk-averse caution to optimistic «dreamings»" [28], perhaps it became a little too arduous to temper its BRI soar.

Inside the EU, positions with reference to the BRI are dissimilar. There is an inconsistent sense of coordination and communication at the level of representation. On top of all this, competition between Member States over who might win China and who might have the strength to reduce some of the EUChina trade deficit are other realities that impact the BRI. Undoubtedly "a requirement for reciprocal opening has entered European policy statements on China. [...] This is not a turn to protectionism. Europe seeks engagement rather than confrontation..."[29]. In either case, "China could take advantage of a divided Europe, as Brexit and the European appetite for Chinese investments will obviously strengthen Beijing's bargaining powers... but the success of "One Belt, One Road" largely depends on the participants' ability to manage multilateral projects" [30]. Looking thoroughly at the examples provided by the specialized literature, it is utterly important to mention that "Berlin was among the first European capitals - if not the first - formally to endorse the initiative" [31]. An argument that may support this assumption is that Germany has remained strong throughout the financial crisis, constant toward delivering its leadership stances and committed to political maturity. Perceiving through the lens of an intrinsic angle, bilateral and multilateral settings become possibly hard to differentiate due to the welter of initiatives and ambitions. At the beginning of this year, "both the President of the Italian Republic, Sergio Mattarella, and French Prime Minister, Bernard Cazeneuve, paid state visits to China... [where] both countries presented their own assets for completion of the new Silk Road..."[32]. Furthermore, Greece and Portugal seemingly are in the center of debates equally due to the compelling investments received lately [33].

While the Western part of the EU is impregnated in pride and statements of all sorts, their Eastern counterparts leave the impression that somehow they managed already to settle down on an outline regarding China's approach per se. Central and Eastern Europe (CEE) in this equation becomes, therefore, the forefront of BRI's European prospects. In another train of thought, the $16+1$ framework paved the way for a tête-à-tête approach of SinoEuropean relations. Eleven out of the sixteen actors that participate in this framework are Member States of the EU [34]. Thence, some scholarly stances believe that China's desire is divide and rule [35]. Yet I do not share this opinion. CEE, within this conjecture, is actually in the most favorable position. After all, the $16+1$ framework has the potential to empower the region within the EU, and similar concepts arose, such as The Three Seas Initiative [36], which indicates that special attention to the region is acclimatized. One similar posture is expressed by Iulia Monica Oehler-Şincai and Liu Minru: "China's intention is not to generate a "divide et impera" effect, but to benefit from the existing opportunities offered by the 
regional networking" [37]. Considering the fact that CEE's EU membership took place only for a decade or so, the majority of the region's countries seek to have a greater say in European politics. These countries also might still have an impulse of bilateralism due to the fact that their European counterparts mistrusts them in terms of capabilities. A particular case of CEE leadership with respect to the BRI though is represented, from my perspective, by Hungary, Poland and Serbia [38]. I would regard this trio as the most successful in approaching China in the region, demonstrating initiative, cordiality and pragmatism.

\section{ASSESSING ROMANIA'S POSITION WITHIN THE BRI}

When assessing Romania's particular position regarding China's BRI, it is notable to mention that reactions were similar to the European ones and "no in-depth analysis" [39] has been provided "until the end of 2016" [40]. By any means, "Romania's interests in the framework of the $16+1$, and implicitly BRI, focuses on the areas of energy, agriculture, infrastructure, communications, IT, and tourism, but also cooperation in other areas where viable projects are identified. Romanian authorities are interested in capitalizing on strategic advantages arising from is status of EU member states and Black Sea and Danube riparian state, in order to facilitate the transit of goods between China and the EU" [41].

Despite the fact that Sino-Romanian relations, prior to 1989 , were unique, based on thorough mutual support, this trend did not remain linear [42]. As a result, it is possible to characterize today's bilateral state of the art as "not in [the] strategic"[43] perspective. Overlapping and generally endorsed scholarship arguments debate the fact that "Romania's relationship with China and other traditional partners decreased in intensity during the process of EU accession and integration"[44]. Nonetheless, it became obvious that
"Romania lost numerous opportunities, including the historical advantages in developing economic cooperation with the largest emerging economy, China"[45].

Regarding to some recent communiqués issued by the Romanian Ministry of Foreign Affairs, it is critical to observe that its positions gained some sort of a pattern: not only have they been delivered under the accustomed $16+1$ framework, but also in most part of the bilateral meetings and major summits, Romania was exclusively represented by state secretaries [46]. For example, at the 2015 China-CEE Summit, held in Suzhou, Romania sent cabinet level ministers, "even though the meeting was dedicated to presidents or prime ministers" [47], while Bulgaria, Estonia, Hungary or Poland were all represented at a higher level. In Suzhou, Romania did not manage to sign significant accords in the light of the BRI[48].

\section{CONCLUSION}

In terms of bilateral relations, the lack of commitment from the Romanian side still brings a cooperation at the level of political correctness. The successive domestic changes have impacted Romania's foreign relations, especially those with the Far East. In many circumstances, Romania lacks pragmatism when tackling international relations due to the internal struggles for power, while things seem to have already been caught up in some sort of a vicious repetitiveness. Therefore, in contrast, Romania shows successive signs of drowsiness when discussing the BRI.

Romanian academics pertaining to China's BRI is fractured and dismissed by governmental agents. Moreover, Iulia Monica Oehler-Șincai from the Romanian Academy, as well as young scholars of the Romanian Institute for the Study of the Asia-Pacific, undertook a series of researches and analysis that debate the BRI, explain Romania's potential gain from the project, and observe closely the evolution of China's actions and reactions in CEE. In another train of thought, Oehler-Şincai and 
Liu Minru, in one of their latest research, conducted a series of interviews with government officials, Sinologists and journalists, in Romania. One piece of this researched entitled Romanian government supports strengthening cooperation relations with China? - Yes; - No; - I do not know"[49]. Admittedly, Oehler-Șincai and Liu conclude that this "let to positive answers among the ministerial experts and negative answers among the Sinologists and journalists"[50].

On the other hand, there are several more optimistic aspects worth mentioning. Firstly, $16+1$ Summit, in 2013, was held in
Bucharest[51] Secondly, Romania recently decided to host the Center for Dialogue and Cooperation on Energy Projects under the same framework. Thirdly, the reiteration and reassurance of the $16+1$ 's objectives became known as the Bucharest Guidelines for Cooperation [52] Fourthly, "the Romanian government [...] approved the start of discussions on the conditions under which the country could become a member of the AIIB...."[53]. Lastly, Romania was the second (CEE) country that "signed a $\mathrm{MoU}$ for the development of bilateral cooperation in the economic zone of the Silk Road"[54].

\section{References}

[1] In mid-2016, a communiqué was released by the Central Compilation and Translation Bureau of the People's Republic of China and the Chinese Academy of Social Sciences indicating that the English official name of the 一带一路 [yi dai yi lu] had been revised. Known until then as the One Belt One Road Initiative, it is now referred to as the Belt and Road Initiative (BRI). For further reference, please see Una Aleksandra BērzinaČrenkova, "BRI Instead of OBOR - China Edits the English Name of its Most Ambitious International Project", in Latvian Institute of International Affairs, July 28, 2016, http://liia.lv/en/analysis/bri-instead-of-obor-china-edits-the-english-name-of-itsmost-ambitious-international-project-532 (accessed December 9, 2017).

[2] Maximilian Mayer, "China's Rise as Eurasian Power: The Revival of the Silk Road and Its Consequences", in Rethinking the Silk Road. China's Belt and Road Initiative and Emerging Eurasian Relations, ed. Maximilian Mayer, Singapore: Palgrave Macmillan, 2018, 2.

[3] Jinchen Tian, "“One Belt and One Road»: Connecting China and the world".

[4] Jinchen Tian, "“One Belt and One Road": Connecting China and the world", McKinsey \& Company, July, 2016, https://www.mckinsey.com/industries/capital-projects-andinfrastructure/our-insights/one-belt-and-one-road-connecting-china-and-the-world (accessed November 17, 2017).

[5] Maximilian Mayer, "China's Rise as Eurasian Power: The Revival of the Silk Road and Its Consequences", 6.

[6] For further reference, please see Maximilian Mayer, "China's Rise as Eurasian Power: The Revival of the Silk Road and Its Consequences", 6-7.

[7] Bogdan Góralczyk, "China's interests in Central and Eastern Europe: enter the dragon", European View 16, no. 1 (2017): 155.

[8] Xie Tao, "Chinese Foreign Policy With Xi Jinping Characteristics", Carnegie-Tsinghua Center for Global Policy, November 20, 2017, http://carnegietsinghua.org/2017/11/20/chinese-foreign-policy-with-xi-jinpingcharacteristics-pub-74765 (accessed November 30, 2017).

[9] Maximilian Mayer, "China's Rise as Eurasian Power: The Revival of the Silk Road and Its Consequences", 2. 
[10] Yu Cheng, "Public Opinions on the Belt and Road Initiative: A Cross-Cultural Study", in The Belt and Road Initiative in the Global Arena. Chinese and European Perspectives, eds. Yu Cheng, Lilei Song and Lihe Huang (Singapore: Palgrave Macmillan, 2018), 1.

[11] Government of the People's Republic of China, The National Development and Reform Commission, Ministry of Foreign Affairs, and Ministry of Commerce (with State Council authorization), Vision and Actions on Jointly Building Silk Road Economic Belt and 21st-Century Maritime Silk Road, 2015, Beijing, March 28, 2015, http://en.ndrc.gov.cn/newsrelease/201503/t20150330_669367.html (accessed December 3, 2017).

[12] Zuokui Liu, "The "16+1 Cooperation" under the "Belt and Road" initiative", in China's Relations with Central and Eastern Europe. From "Old Comrades" to New Partners, ed. Weiqing Song (London, New York: Routledge, 2018), 29.

[13] For further reference, please see "Our bulldozers, our rules", The Economist, July 2, 2016, https:/www.economist.com/news/china/21701505-chinas-foreign-policy-couldreshape-good-part-world-economy-our-bulldozers-our-rules (accessed November 28, 2017).

[14] Peter Ferdinand, "Westward ho - the China dream and "One Belt, One Road". Chinese foreign policy under Xi Jinping", in China's Relations with Central and Eastern Europe. From "Old Comrades" to New Partners, ed. Weiqing Song (London, New York:

Routledge, 2018), 22.

[15] For further reference, please see Maximilian Mayer, "China's Rise as Eurasian Power: The Revival of the Silk Road and Its Consequences", in Rethinking the Silk Road. China's Belt and Road Initiative and Emerging Eurasian Relations, ed. Maximilian Mayer (Singapore: Palgrave Macmillan, 2018), 7; and Yang Minghong, "Understanding the One Belt One Road Initiative: China's Perspective", in China's One Belt One Road. Initiative, Challenges and Prospects, eds. Bal Krishan Sharma and Nivedita Das Kundu (New Delhi: Vij Books India Private Limited, 2016), 10-13.

[16] For further reference, please see Maximilian Mayer, "China's Rise as Eurasian Power: The Revival of the Silk Road and Its Consequences", 7-8.

[17] For further reference, please see Maximilian Mayer, "China's Rise as Eurasian Power...", 3-4.

[18] Peter Ferdinand, "Westward ho - the China dream and "One Belt, One Road". Chinese foreign policy under Xi Jinping", 18.

[19] For further reference, please see Andreea Brînză, "Yiwu-Londra: un nou drum de fier al mătăsii pe panoplia OBOR", The Romanian Institute for the Study of the Asia-Pacific, January 4, 2017, http://risap.ro/yiwu-londra-un-nou-drum-de-fier-al-matasii-pepanoplia-obor/ (accessed December 1, 2017).

[20] Peter Ferdinand, "Westward ho - the China dream and "One Belt, One Road". Chinese foreign policy under Xi Jinping", 18.

[21] For further reference, please see Peter Ferdinand, "Westward ho - the China dream and "One Belt, One Road". Chinese foreign policy under Xi Jinping", in China's Relations with Central and Eastern Europe. From "Old Comrades" to New Partners, ed. Weiqing Song (London, New York: Routledge, 2018), 18.

[22] Bogdan Góralczyk, "China's interests in Central and Eastern Europe: enter the dragon", European View 16, no. 1 (2017): 154. 
[23] Lai Suetyi, "Understanding Europe's Interest in China's Belt and Road Initiative", Carnegie-Tsinghua Center for Global Policy, May 10, 2017, http://carnegietsinghua.org/2017/05/10/understanding-europe-s-interest-in-china-s-beltand-road-initiative-pub-69920 (accessed December 1, 2017).

[24] Id est, the Asian Infrastructure Investment Bank (AIIB). Launched in 2013, the Chinaled AIIB is a key institution concerning the BRI. For further reference, please see Lai Suetyi, "Understanding Europe's Interest in China's Belt and Road Initiative", CarnegieTsinghua Center for Global Policy, May 10, 2017, http://carnegietsinghua.org/2017/05/10/understanding-europe-s-interest-in-china-s-beltand-road-initiative-pub-69920 (accessed December 1, 2017).

[25] Lai Suetyi, "Understanding Europe's Interest in China's Belt and Road Initiative".

[26] Philippe Le Corre, "Chinese Investments in European Countries: Experiences and Lessons for the "Belt and Road" Initiative", in Rethinking the Silk Road. China's Belt and Road Initiative and Emerging Eurasian Relations, ed. Maximilian Mayer (Singapore: Palgrave Macmillan, 2018), 162.

[27] Shi Zhiqin, "China-EU Relations: Crisis and Opportunity", Carnegie-Tsinghua Center for Global Policy, March 15, 2016, http://carnegietsinghua.org/2016/03/15/china-eurelations-crisis-and-opportunity-pub-63049 (accessed December 2, 2017).

[28] Peter Ferdinand, "Westward ho - the China dream and "One Belt, One Road". Chinese foreign policy under Xi Jinping", 23.

[29] François Godement and Abigaël Vasselier, "China at the Gates: A New Power Audit of EU-China Relations", Carnegie-Tsinghua Center for Global Policy, December 1, 2017, http://carnegieendowment.org/2017/12/01/china-at-gates-new-power-audit-of-eu-chinarelations-pub-74919 (accessed December 12, 2017).

[30] Sebastien Goulard, "France, Italy, and China's 'Belt and Road' Initiative", The Diplomat, March 7, 2017, https://thediplomat.com/2017/03/france-italy-and-chinas-belt-and-roadinitiative/ (accessed December 12, 2017).

[31] Wolfgang Röhr, "Berlin Looking Eastward: German Views of and Expectations from the New Silk Road", in China's Relations with Central and Eastern Europe. From "Old Comrades" to New Partners, ed. Weiqing Song (London, New York: Routledge, 2018), 227.

[32] Sebastien Goulard, "France, Italy, and China's 'Belt and Road' Initiative".

[33] For further reference, please see Philippe Le Corre, "Chinese Investments in European Countries: Experiences and Lessons for the "Belt and Road" Initiative", 165-171.

[34] Government of Romania, Ministry of Foreign Affairs, Participarea secretarului de stat pentru afaceri bilaterale globale, Monica Gheorghiță, la reuniunea coordonatorilor naționali ai Cooperării China - Europa Centrală şi de Est (16+1), Bucharest, October 11, 2017, http://mae.ro/node/43598 (accessed December 2, 2017).

[35] For further reference, please see Richard Turcsányi, "Central and Eastern Europe's courtship with China: Trojan horse within the EU?", in EU-Asia at a Glance, European Institute for Asian Studies, January, 2014, http://www.eias.org/wpcontent/uploads/2016/02/EU-Asia-at-a-glance-Richard-Turcsanyi-China-CEE.pdf (accessed April 12, 2017); and Dragan Pavlićević, "China in Central and Eastern Europe: 4 Myths", The Diplomat, June 16, 2016, https://thediplomat.com/2016/06/china-in-central-and-eastern-europe-4-myths/ (accessed December 12, 2017).

[36] The Three Seas Initiative is also known as the Baltic, Adriatic, Black Sea (BABS) Initiative. BABS is a forum of the EU's CEE component. 
[37] Iulia Monica Oehler-Șincai and Liu Minru, "Sino-Romanian relations under the New World Order", in China's Relations with Central and Eastern Europe. From "Old Comrades" to New Partners, ed. Weiqing Song (London, New York: Routledge, 2018), 171.

[38] For further reference, please see The Romanian Institute for the Study of the AsiaPacific, "Summitul China-CEE: România nu a prins trenul de pe Drumul Mătăsii", December 2, 2015, http://risap.ro/summitul-china-cee-romania-nu-a-prins-trenul-de-pedrumul-matatsii/ (accessed November 30, 2017); and The Romanian Institute for the Study of the Asia-Pacific, "One Belt, One Road își face drum prin Ungaria", http://risap.ro/one-belt-one-road-isi-face-drum-prin-ungaria/, June 23, 2015 (accessed November 30, 2017).

[39] Iulia Monica Oehler-Șincai and Liu Minru, op. cit., 187.

[40] Idem.

[41] Ibidem.

[42] For further reference, please see Iulia Monica Oehler-Şincai and Liu Minru," SinoRomanian Relations under the New World Order", in W. Song, China's Relations with Central and Eastern Europe, Routledge, NY, 2017, 175-176.

[43] Iulia Monica Oehler-Șincai and Liu Minru, op. cit., 171.

[44] Ibidem, 175.

[45] Idem.

[46] For further references, please see Government of Romania, Ministry of Foreign Affairs, România va găzdui prima conferință ministerială și târgul în domeniul energiei $\hat{\imath} n$ cadrul formatului de cooperare China - Statele Europei Centrale și de Est (,,16+1"), Bucharest, November 6, 2017, http://mae.ro/node/43935 (accessed December 13, 2017); Participarea secretarului de stat pentru afaceri bilaterale globale, Monica Gheorghiță, la reuniunea coordonatorilor naționali ai Cooperării China - Europa Centrală şi de Est (16+1), Bucharest, October 11, 2017, http://mae.ro/node/43598 (accessed December 12, 2017); România va organiza la București Forumul partidelor politice din formatul Cooperării China - Europa Centrală şi de Est (16+1), Bucharest, July 11, 2017, http://mae.ro/node/42469 (accessed December 12, 2017); Participarea secretarului de stat Alexandru Victor Micula la reuniunea coordonatorilor naţionali ai Forumului de cooperare China - Europa Centrală şi de Est (16+1), Bucharest, October 14, 2016, http://mae.ro/node/38811 (accessed December 12, 2017); Consultări bilaterale intre secretarul de stat pentru afaceri globale, Daniela Gîtman, și ministrul asistent al afacerilor externe din Republica Populară Chineză, Liu Haixing, Bucharest, September 23, 2016, http://mae.ro/node/38500 (accessed December 12, 2017); Intrevederea secretarului de stat Daniela Gîtman cu delegația Comisiei pentru afaceri externe a Adunării Naționale Populare a R. P. Chineze, Bucharest, July 12, 2016, http://mae.ro/node/37768 (accessed December 12, 2017); Participarea secretarului de stat Alexandru Victor Micula la reuniunea coordonatorilor naţionali ai Cooperării China - Europa Centrală şi de Est, Bucharest, June 27, 2016, http://mae.ro/node/37600 (accessed December 12, 2017); Intrevederea secretarului de stat Radu Podgorean cu o delegație de lucru a MAE chinez pentru cooperarea ,, 16+1”, Bucharest, January 19, 2016, http://mae.ro/node/35394 (accessed December 12, 2017); Participarea secretarului de stat Radu Podgorean la reuniunea coordonatorilor naționali ai formatului de cooperare R. P. Chineză-Europa Centrală și de Est, Bucharest, October 28, 2015, http://mae.ro/node/34372 (accessed December 12, 2017); Participarea secretarului de stat Radu Podgorean la reuniunea coordonatorilor naţionali ai Cooperării China - state din Europa Centrală și de Est, Bucharest, July 13, 2015, http://mae.ro/node/32881 (accessed December 12, 2017); and Participarea secretarului 
de stat Radu Podgorean la reuniunea coordonatorilor naţionali din Forumul de cooperare China -ECE, Bucharest, May 13, 2014, http://mae.ro/node/26655 (accessed December 12, 2017).

[47] ***, "Summitul China-CEE: România nu a prins trenul de pe Drumul Mătăsii", The Romanian Institute for the Study of the Asia-Pacific, December 2, 2015, http://risap.ro/summitul-china-cee-romania-nu-a-prins-trenul-de-pe-drumul-matatsii/ (accessed December 2, 2017).

[48] Idem.

[49] Iulia Monica Oehler-Șincai and Liu Minru, op. cit., 193.

[50] Ibidem, 193.

[51] For further reference, please see Investment and Development Agency of Latvia, About 16+1, 2016, http://ceec-chinalatvia.org/page/about (accessed May 19, 2017).

[52] For further reference, please see "The Bucharest Guidelines for Cooperation between China and Central and Eastern European Countries", Xinhua News Agency, January 26, 2015, http://www.chinaceec.org/eng/ldrhw_1/2013bjlst/hdxw1/t1410529.htm (accessed May 19, 2017).

[53] Janne Suokas, "Romania seeks to join Asian Infrastructure Investment Bank", GB Times, June 3, 2016, http://gbtimes.com/business/romania-seeks-join-asian-infrastructureinvestment-bank (accessed February 16, 2017).

[54] Iulia Monica Oehler-Șincai and Liu Minru, op. cit., 188. 